\title{
FAKTOR YANG MEMPENGARUHI ANAK USIA SD TAAT PADA PERATURAN SEKOLAH
}

\author{
Siti Muhayati *) \\ sitimuhayati10@gmail.com \\ Melik Budiarti **) \\ melikbudiarti74@gmail.com
}

\begin{abstract}
Abstrak
Teori awal yang dijadikan landasan penelitian ini adalah: Pola asuh orang tua, Iman pada kitab Allah, Taat.

Penelitian ini dengan menggunakan metode penelitian kualitatif. Teknik pengambilan sampel secara snowball sampling dari populasi 150. Teknik pengumpulan data dengan triangulasi. Analisa datanya model Spradley

Hasil penelitian: 1. Faktor eksternalnya : a. Pola asuh dialogis b. Teman sebaya c. Lingkungan sekolah kondusif.. 2. Faktor internalnya:a. Iman pada kitabulloh, b.Baca Al Qur'an, c. Melaksanakan peraturan Al Qur'an dan Al Hadits.
\end{abstract}

Kata kunci: Faktor, Anak Usia Sekolah Dasar, Taat, Peraturan Sekolah

\section{Abstract}

Early theories were used as the basis of this research are: Pattern foster parent, Faith in God's book, Obedient.

This research using qualitative research methods. Snowball sampling technique sampling of a population of 150. The data collection technique by triangulation. Data analysis models Spradley

Result: The external factors: 1. a. Parenting Dialogic b. Peers $c$. The school environment conducive. 2. The internal factors: a. Faith in kitabulloh, b. Baca Qur'an, c. Implement regulations Qur'an and Al Hadith

Keywords: Factors, Childhood Elementary School, Obedient, Rule School

* Siti Muhayati adalah Dosen Program Studi Pendidikan Teknik Elektro Fakultas Ilmu Pendidikan IKIP PGRI MADIUN.

** Melik Budiarti adalah Dosen Program Studi Pendidikan Guru Sekolah Dasar Fakultas Ilmu Pendidikan IKIP PGRI MADIUN.

\section{Pendahuluan}

Tiap anak dilahirkan dalam keadaan fithrah, maka ayahnyalah anak tersebut menjadi baik atau buruk. Mengapa ayah? karena ayah adalah pemegang konsep hidup mau 
dibawa kemana keluarga tersebut khususnya isteri dan anaknya. Ayah pemberi konsep yang harus dilakukan oleh istri dan anaknya. Ayah yang berkonsep dan berbudaya illahiyah maka istri dan anaknya berkonsep dan berbudaya illahiyah juga. Sedangkan istri menanamkan konsep dan budaya illahiyah. Jadi anak menjadi baik atau buruk tergantung pada kedua orang tuanya.

Konsep illahiyah adalah konsep hidup yang dibuat oleh Allah yang berupa peraturan peraturan yang mengatur cara manusia bersikap kepada Allah dan bersikap kepada sesama manusia dan alam semesta. Konsep tersebut dikenal dengan Islam.

Diantara peraturan Islam adalah peraturan tentang iman. Iman adalah mempercayai Adanya Allah dan peraturanNya. Peraturan Allah tercantum dalam Al Qur'an dan Hadits, selanjutnya Al Qur'an dikenal sebagai kitab Allah. Kitab Allah ini selain diimani juga wajib dibaca, difahami, dihayati, diamalkan dan dibela. Jika manusia seperti itu maka mereka akan tahu peraturan dan mentaati.
Negara Kesatuan Republik Indonesia adalah negara hukum dimana negara mengatur warga negara, jika negara mengatur berarti ada peraturan. Peraturan tersebut tercantum dalam Pancasila, UDD 1945, Undang-undang dan lain lain. Idealnya warga negara taat peraturan, kapan dimulai? ketika warga negara masih usia balita, selanjutnya bisa diamati pada usia Sekolah Dasar. Faktor apa saja yang mempengaruhi anak usia Sekolah Dasar taat pada peraturan Sekolah?

Tinjauan pustaka dari penelitin ini adalah:

Pola Asuh Orang Tua. Tiap anak dilahirkan dalam keadaan suci(potensi dasar), maka ayah dan ibunya yang bisa menjadikan anak menjadi baik atau buruk. Orang tua adalah sebagai pendidik pertama dan utama, orang memperkenalkan konsep hidup dan budaya yang dipegangi oleh ayah dan ibu. Cara untuk menanamkan konsep dan budaya ada beberapa pola yaitu:

Pola Asuh Otoriter.Otoriter ini merupakan pola asuh orang tua dimana semua keiinginan orang tua harus dituruti oleh anak tanpa 
pengecualian. Disini anak tidak bisa memberikan pendapat dan hanya harus mengikuti kemauan orang tua. Biasanya kemuan dari orang tua tersebut tanpa diberikan alasan. Akibatnya bisa membuat anak "Depresi". Apabila anak tersebut berhasil mengikuti pola asuh yang seperti ini maka anak akan bersifat seperti orang tuanya. Contoh pola asuh diktator (otoriter) yang paling banyak terjadi, Ayah memaksa anaknya untuk masuk ke jurusan kedokteran. Dimana si anak tidak menyukai jurusan tersebut. Akan tetapi, ayah tersebut terus memaksa sampai keiinginannya terpenuhi. Ayahnya tidak menjelaskan kepada anaknya, kenapa anaknya harus memilih jurusan tersebut. Yang ada ayahnya mengatakan, pokoknya kamu harus masuk jurusan kedokteran. Ketika si anak menyetujui kemauan dari ayahnya, yang ada si anak tidak bisa beradaptasi dengan lingkungannya. Yang membuat si anak tadi menjadi tertekan bahkan sampai depresi. Contoh lainnya, orang tua tidak mengizinkan anaknya untuk kawin dengan suku Batak misalnya.

\section{Pola Asuh Demokratis}

Demokratis ini merupakan pola asuh yang paling baik. Dimana orang tua bersikap friendly dan anak bebas mengemukakan pendapatnya. Disini orang tua lebih mau mendengar keluhan dari anaknya, mau memberikan masukan. Ketika anaknya diberi hukuman, orang tua menjelaskan kenapa dia harus dihukum. Pola asuh ini menurut saya tidak banyak dimiliki oleh orang tua zaman sekarang. Contoh dari pola asuh ini, dimana orang tua mau mendengarkan curhat dari anaknya, mau memberikan solusi dari masalah yang dihadapi anaknya. Orang tua lebih mengajarkan anak untuk lebih baik, misalnya mengetuk pintu sebelum masuk rumah dan menjelaskan kenapa harus melakukan hal itu.

\section{Pola Asuh Temporizer.}

Temporizer ini merupakan pola asuh yang sangat tidak konsisten. Dimana orang tua tidak memiliki pendirian. Contoh dari pola asuh ini seperti, anak yang diberikan batas waktu pulang malam sekitar jam 10 . Terkadang orang tuanya tidak memarahi anaknya, jika anaknya 
pulang lebih lama dari itu, tapi terkadang juga orang tua marah besar kepada anaknya jika lewat pada waktunya. Ini membuat anak bingung. Sebenarnya yang bolehnya seperti apa?? Akan muncul macam tanya dalam diri anak.

\section{Pola Asuh Appeasers.}

Appeasers ini merupakan pola asuh dari orang tua yang sangat khawatir akan anaknya, takut menjadi yang tidak baik pada anaknya (overprotective). Contohnya, orang tua memarahi anaknya jika bergaul dengan anak tetangga. Karena takut menjadi tidak benar. Orang tua tidak mengizinkan anaknya untuk pergi camping, karena takut terjadi yang tidak diinginkan. Ini membuat anak menjadi tidak bebas.

Pola Asuh Permisif. Tipe orang tua yang mempunyai pola asuh permisif cenderung selalu memberikan kebebasan pada anak tanpa memberikan kontrol sama sekali. Anak sedikit sekali dituntut untuk suatu tangung jawab, tetapi mempunyai hak yang sama seperti orang dewasa. Anak diberi kebebasan untuk mengatur dirinya sendiri dan orang tua tidak banyak mengatur anaknya. Menurut Spock (Aisyah, 2010) orang tua permisif memberikan kepada anak untuk berbuat sekehendaknya dan lemah sekali dalam melaksanakan disiplin pada anak. Hurlock (Aisyah, 2010) mengatakan bahwa pola asuhan permisif bercirikan adanya kontrol yang kurang, orang tua bersikap longgar atau bebas, bimbingan terhadap anak kurang. Ciri pola asuh ini adalah semua keputusan lebih banyak dibuat oleh anak daripada orang tuanya. Contoh, anak tidak diberi batas jam malam, artinya mau anaknya pulang pagi, orang tua tidak mempedulikannya dan tidak menanyakan. Terlalu memberikan kebebasan sama anak sangat tidak baik untuk anak, karena anak bisa jadi salah bergaul, tapi terlalu khawatir akan anak juga tidak baik, anak akan sulit untuk bergaul. Jadi, intinya orang tua harus bisa bersikap demokratis kepada anaknya.

Iman Pada Kitab Allah. Kitab Allah adalah semua kitab yang berisi peraturan tentang cara hidup di dunia baik yang terkait hubungan manusia dengan Allah dan hubungan manusia dengan manusia dan alam semesta. 
Kitab Allah yang diturunkan untuk kebahagiaan manusia di dunia ada empat yaitu Zabur yang diamanahkan kepada Nabi Daud a.s untuk diajarkan pada kaumnya, Taurat yang diamanahkan pada Nabi Musa a.s, Injil yang diamanahkan pada Nabi Isa a.s, Al Qur'an diamanahkan pada Nabi Muhammad s.a.w. Kitab Allah yang terkait dengan pembahasan ini adalah $\mathrm{Al}$ Qur'an. Al Qur'an yaitu peraturan Allah yang berupa perintah dan larangan yang diamanahkan kepada Nabi Muhammad yang terdiri dari tiga puluh juz, seratus empat belas surat, enam ribu enam ratus enam puluh enam ayat, melalui malaikat Jibril, diperintahkan untuk membaca, diriwayatkan secara mutawatir, diawali dengan surat al fatihah dan diakhiri dengan surat an nas. Kandungan isi Alqur'an adalah peraturan tentang aqidah/iman, peraturan hubungan manusia dengan Allah, hubungan manusia dengan manusia dan alam semesta, peraturan tentang pengkondisian suasana hati..

Fungsi Al Qur'an. Al Qur'an berfungsi sebagai Al huda (petunjuk) bagi manusia, Alfurqon(pembeda) antara yang haq dan yang bathil, Ad dzikr(peringatan) bagi orang orang yang taqwa, Asyifa'(obat) bagi yang ruh yang lara, mau'idhoh(tauladan) bagi manusia, bahan renungan bagi yang mau berfikir, sumber pengetahuan.

\section{Lingkungan}

sekolah

kondusif. Lingkungan sekolah kondusifsehingga anak taat pada peraturan sekolahPerkembangan Pengertian Norma. Kapan anak mengerti norma/moralitas maka menurut Pieget (dalam Siti Rahayu M, 2004:198) mengatakan bahwa anak sadar akan aturan, realisme moral dan pengertian akan keadilan harus dimulai dengan aturan aturan misalnya aturan permainan, karena aturan mengandung arti menghormat, hormat pada orang lain. Hasil penyelididka Pieget tentang kesadaran akan aturan adalah bahwa anak mempunyai pendapat yang obsolut dan penilian yang obsolut. Anak kecil tidak bersedia untuk mengalah dalam menilai sesuatu. Hal sesuatu benar atau salah tidak ada pertimbangan faktor situasional. Setelah umur 8 tahun anak lebih fleksibel dalam penilaiannya dan 
lebih mampu untuk memperhatikan faktor situasional dalam menilai sesuatu.

Dari uraian diatas maka muncul permasalahan: Faktor apa yang mempengaruhi anak usia sekolah dasar tata pada peraturan sekolah. Tujuan penulisan artikel ini adalah untukMengetahui faktor intern yang mempengaruhi anak usia Sekolah Dasar taat pada peraturan Sekolah; Mengetahui faktor extern yang mempengaruhi anak usia Sekolah Dasar taat pada peraturan Sekolah

\section{Metode Penelitian}

Penelitian ini dengan menggunakan metode penelitian kualitatif. Teknik pengambilan sampel secara snowball sampling dari populasi 150. Teknik pengumpulan data dengan trianggulasi. Analisa datanya model Spradley.

\section{Hasil Penelitian.}

Hasil penelitian menunjukan bahwa:

Faktor eksternal anak taat peraturan di sekolah adalah:

- Pola asuh dialogis yaitu anak . dibiasakan mentaati peraturan oleh orang tuanya, dibiasakan memenej waktu,

- Teman sebaya yang memperoleh pembiasaan yang sama dalam keluarganya msing-masing.

- Lingkungan sekolah kondusif sehingga anak taat pada peraturan sekolah.

Faktor internal anak taat peraturan di sekolah adalah:

Terinternalisasi nilai nilai dari pembiasaan pembiasaan yaitu:

- Iman pada kitabulloh(AlQur'an)

- Baca Al Qur’an

- Melaksanakan peraturan $\mathrm{Al}$ Qur'an dan Al Hadits (baca syarat dan rukun sholat, puasa dan lain lain)

\section{Pembahasan}

Hasil penelitian menunjukan bahwa: faktor yang mempengaruhi anak usia sekolah dasar adalah faktor ekternal dan internal.

Faktor eksternal adalah;

1. Pola asuh dialogis.Pola asuh secara garis besar ada dua yaitu Pola asuh dialogis.Pola asuh dialogis yaitu pola asuh orang tua dimana orang tua memelihara, mengasuh, 
membina, mendidik dan mengembangkan

fithrah(potensi) anak dari waktu ke waktu sesuai dengan fithrah penciptaan manusia sebagai hamba Allah dan kholifah fil ard. Dalam pola asuh ini, orang tua membimbing, mengamati dan mengingatkan anak, memberi contoh dan menjawab pertanyaan anak dengan jawaban yang sesuai dengan usianya. Akibat pola asuh ini terhadap anak ialah anak akan selalu percaya diri, mandiri, hidupnya berarti, dan menjauhi segala keburukan bukan karena orang tua, tetapi karena dia merasakan akibat keburukan tersebut( Ummu Dini:2004).

Pengetrapan pola asuh dialogis ini dalam pembentukan sikap taat peraturan yaitu dimana orang tua mengajari anak untuk taat pada peraturan baik peraturan dari Allah, Rasul, uli amri ataupun peraturan yang dibuat yang berlaku dalam lingkup keluarga, selain itu orang tua memberi contoh pada anaknya bahwa orang tua selalu taat peraturan baik ada anak atau tidak anak didepan mereka, karena orang tua sebgai figur pertama dan utama dalam membentuk sikap anak taat pada peraturan. Tinggi rendahnya sikap tata peraturan tergantung pada tinggi rendahnya orang tua taat ada peraturan. Sebagaimana Sabda Nabi Muhammad S.A.W. yang artinya:

Anak dilahirkan dalam keadaan suci sampai lisannya mengucapkan kehendak dirinya maka tergantung ayahnya, anak menjadi yahudi, nasrani atau majusi (H.R. Al-Aswad bin Surai).

Disamping orang tua membimbing dan memberi contoh, orang tua mengajak dialog mengenai hikmah taat pada peraturan.. Dalam hal ini hikmah taqwa yaitu manusia selain mematuhi peraturan Allah dan rasulNya juga uli amri termasuk peraturan yang berlaku di sekolah.

Menuruth Amad Tafsir pola asuh dialogis adalah: Penambahan pengetahuan, Pembinaan Ketrampilan, Memberikan contoh atau 
teladan, Membiasakan(tentunya yang baik), Menegakan Disiplin; Memberikan Motivasi atau dorongan; Memberikan hadiah terutama psikologis; Menghukum( mungkin dalam kedisiplinan);Menciptakan suasana yang berpengaruh bagi pertumbuhan positif.

Menurut Amir Ahmad Sulaiman pola asuh dialogis yang terkait dengan berbusana sesuai jenis kelaminnya sebagi berikut: Membimbing (mengajarinya); Mengamati; Mengingatkan; Menjawab pertanyaan dengan jawaban yang sesuai usianya.

Jadi pola asuh dialogis dalam taat pada peraturan dapat dilakukan sebagai berikut: Penambahan pengetahuan, Pembinaan Ketrampilan, Memberikan contoh atau teladan, Membiasakan (tentunya yang baik), Menegakan Disiplin; Memberikan Motivasi atau dorongan; Memberikan hadiah terutama psikologis; Menghukum (mungkin dalam kedisiplinan);Menciptakan suasana yang berpengaruh bagi pertumbuhan positif; Menjawab pertanyaan anak dengan jawaban yang sesuai usianya.( Siti Muhayati, 2010)

Jika anak diasuh dengan pola asuh permisif maka anakanak berkarakter impulsive, agresif, tidak patuh, manja, kurang mandiri, mau menang sendiri, kurang percaya diri. Adapun Pola asuh Permisif adalah pola asuh dimana orang tua memberikan pengawasan yang sangat longgar, memberikan kesempatan pada anak tanpa pengawasan yang cukup darinya. Ciri pola asuh pada orang tua adalah bahwa orang tua tidak mau menegur atau memperingatkan anak apabila anak dalam bahaya, sangat sedikit bimbingan, bersifat hangat sehingga disenangi anak-anak.

2. Teman sebaya yang memperoleh pembiasaan yang sama dalam keluarganya msing-masing. Anak diluar rumah dan diluar sekolah maka mereka bergaul. dengan teman sebaya. Teman 
sebaya ada yang diasuh dengan pola asuh diaogis dan ada yang diasuh dengan pola asuh yang lain. Akhirnya anak usia sekolah dasar terpengaruh teman sebaya yang diasuh dengan pola asuh tertentu.

3. Lingkungan sekolah kondusif sehingga anak taat pada peraturan sekolah

Perkembangan Pengertian Norma. Kapan anak mengerti norma/moralitas maka menurut Pieget (dalam Siti Rahayu M, 2004:198) mengatakan bahwa anak sadar akan aturan, realisme moral dan pengertian akan keadilan harus dimulai dengan aturan aturan misalnya aturan permainan, karena aturan mengandung arti menghormat, hormat pada orang lain.

Hasil penyelididkan Pieget tentang kesadaran akan aturan adalah bahwa anak mempunyai pendapat yang obsolut dan penilian yang obsolut. Anak kecil tidak bersedia untuk mengalah dalam menilai sesuatu. Hal sesuatu benar atau salah tidak ada pertimbangan faktor situasional. Setelah umur 8 tahun anak lebih fleksibel dalam penilaiannya dan lebih mampu untuk memperhatikan faktor situasional dalam menilai sesuatu.. Perkembangan tanggung jawab obyektif ke arah tanggung jawab subyektif, maju pesat setelah umur 8 tahun.

Anak sampai umur \pm 8 tahun terutama melihat materiilnya yaitu kerugian yang ditimbulkan. Itulah hal yang paling menentukan. Motif dan itikatnya tidakdiperhatikan. Sesudah usia ini nampak motif dan makshud orang ikut diperhatikan.

Teori Pieget ini dikembangkan dan diberi dasar teoritis oleh Kohlberg(1963). Menurut Kohlberg perkembangan insan kamil rmelalui 6 stadium dan stadium ini dilalui oleh setiap anak, jadi hal ini bersifat universal. Dimana saja tiap anak pasti melalui tahapan ini tapi tidak tergantung usianya.

Kohlberg membagi perkembangan moralitas ke dalam 3 tingkatan yang masing masing dibagi 2 stadium hingga 
keseluruhannya menjadi 6 stadium, sebagai berikut: Tingkatan 1: Penalaran moral yang pra konvensional Mendasarkan pada obyek di luar diri individu sebagai ukuran benar dan salah :Stadium 1. Orientasi patuh dan takut hukuman. Suatu tingkah laku dinilai benar bila tidak dihukum dan salah bila perlu dihukum. Seseorang harus patuh pada otoritas karena otortas tersebut berkuasa.Stadium 2. Orientasi naif egoistis/hedonisme instrumental. Masih mendasarkan pada orang atau kejadian diluar diri individu, namun sudah memperhatikan alasan perbuatannya ;Tingkatan 11. Penalaran Moral yang Konvensional; Stadium 3. Orientasi anak atau person yang baik. Anak bila ia dipandang sebagai anak wanita atau laki laki yang baik, yaitu bila ia dapat berbuat seperti apa yang diharapkan oleh orang lain atau oleh masyarakat; Stadium 4. Orientasi pelestarian otoritas dan aturan sosial. Anak melihat aturan sosial yang ada sebagai sesuatu yang harus dijaga dan dilestarikan. Seseorang dipandang bermoral bila ia melakukan tugasnya dan dengan demikian dapat melestarikan aturan dan sistem sosial. Tingkat 111 Penalaran Moral yang Post Konvensional.Memandang aturan aturan yang ada dalam masysrakat tidak absolut, tetapi relatif, dapat diganti 0leh yang lain. Stadium 5 Orientasi kontrol legalitasMemahami bahwa peraturan yang ada dalam masyarakat merupakan kontrol (perjanjian) antara diri orang dan masyarakat. Individu harus memenuhi kewajibankewajibannya , tetapi sebaliknya masyarakat juga harus menjamin kesejahteraan individu.peraturan dalam masyarakat adalah subyektif.; Stadium 6 Orientasi yang mendasarkan atas prinsip dan konseinsia sendiri.

Peraturan dan norma adalah subyektif, begitu juga batasannya subyektif dan tidak pasti.Tingkah laku taat anak sebagai berikut: Stadium 1: 
Anak bersikap taat untuk menghindari hukuman; Stadium 2: Anak bersikap taat untuk memperoleh hadiah dan atau dipandang baik ; Stadium 3: Anak bersikap taat untuk menghindari celaan dan untuk disenangi orang lain; Stadium 4: Anak bersikap taat untuk mempertahankan sistem peraturan sosial yang ada dalam kehidupan bersama; Stadium 5: Bersikap taat sekarang dilakukan karena memenuhi perjanjian bersama yang ada dalam peraturan sosial; Stadium 6: Bersikap taat sekarang dilakukan tidak karena perintah atau norma dari luar, melainkan karena keyakinan sendiri ingin melakukannya.

Faktor internal anak taat peraturan di sekolah adalah:

Terinternalisasi nilai nilai dari pembiasaan pembiasaan yaitu:

1. Iman pada kitabulloh(AlQur'an)

Iman Pada Kitab Allah. Kitab Allah adalah semua kitab yang berisi peraturan tentang cara hidup di dunia baik yang terkait hubungan manusia dengan Allah dan hubungan manusia dengan manusia dan alam semesta. Kitab Allah yang diturunkan untuk kebahagiaan manusia di dunia ada empat yaitu Zabur yang diamanahkan kepada Nabi Daud a.s untuk diajarkan pada kaumnya, Taurat yang diamanahkan pada Nabi Musa a.s, Injil yang diamanahkan pada Nabi Isa a.s, Al Qur'an diamanahkan pada Nabi Muhammad s.a.w.Kitab Allah yang terkait dengan pembahasan ini adalah Al Qur'an. Al Qur'an yaitu peraturan Allah yang berupa perintah dan larangan yang diamanahkan kepada Nabi Muhammad yang terdiri dari tiga puluh juz, seratus empat belas surat, enam ribu enam ratus enam puluh enam ayat, melalui malaikat Jibril, diperintahkan untuk membaca, diriwayatkan secara mutawatir, diawali dengan surat al fatihah dan diakhiri dengan surat an nas.

Kandungan isi Alqur'an adalah peraturan tentang aqidah/iman, peraturan hubungan manusia 
dengan Allah, hubungan manusia dengan manusia dan alam semesta, peraturan tentang pengkondisian suasana hati..

Fungsi Al Qur'an. Al Qur'an berfungsi sebagai Al huda (petunjuk) bagi manusia, Alfurqon(pembeda) antara yang haq dan yang bathil, Ad dzikr(peringatan) bagi orang orang yang taqwa, Asyifa'(obat) bagi yang ruh yang lara, mau'idhoh(tauladan) bagi manusia, bahan renungan bagi yang mau berfikir, sumber pengetahuan.

2. Baca Al Qur'an

Tujuan membaca $\mathrm{Al}$ Qur'an adalah untuk mengetahui peraturan atau norma yangterkandung di dalamnya.Norma. Pengertian. Kata norma berasal dari bahasa Belanda norm, yang berarti pokok kaidah, patokan, atau pedoman. Dalam Kamus Hukum Umum, kata norma atau norm diberikan pengertian sebagai kaidah yang menjadi petunjuk, pedoman bagi seseorang untuk berbuat atau tidak berbuat, dan bertingkah laku dalam lingkungan masyarakatnya, misalnya norma kesopanan, norma agama, dan norma hukum. Namun, ada juga yang berpendapat bahwa istilah norma berasal dari bahasa latin, mos yang merupakan bentuk jamak dari mores, artinya adalah kebiasaan, tata kelakuan, atau ada istiadat.

Norma adalah bentuk nyata dari nilai-nilai sosial di dalam masyarakat yang berbudaya, memiliki aturanaturan, dan kaidah-kaidah, baik yang tertulis maupun tidak. Norma-norma ini mengatur kehidupan manusia dalam bermasyarakat. Di dalam norma terkandung aturan-aturan dan pentunjuk kehidupan mengenai benar dan salah, baik atau buruk, pantas atau tidak pantas, yang harus ditaati oleh warga masyarakat. Jika norma itu dilanggar, si pelanggar akan terkena sanksi. Norma memiliki kekuatan yang mengingat dan memaksa pihak lain untuk 
mematuhi aturan yang berlaku. Jadi, secara sederhana pengertian norma adalah aturan yang mengandung sanksi. Terbentuknya norma didasari oleh kebutuhan demi terciptanya hubungan yang harmonis, selaras, dan serasi di antara warga masyarakat. Jadi norma adalah sekumpulan perangkat yang mengatur manusia yang dijadikan sebagai pedoman kehidupan bermasyarakat.

Anak usia sekolah dasar yang membaca Al Qur'an terbiasa membaca peraturan atau norma.

3. Melaksanakan peraturan $\mathrm{Al}$ Qur'an dan Al Hadits (baca syarat dan rukun sholat, puasa dan lain lain)

\section{Kesimpulan}

Pembahasan diatas bisa disimpulkan bahwa:

1. Faktor eksternal anak taat pada peraturan sekolah adalah:

a. Pola asuh dialogis yaitu anak dibiasakan mentaati peraturan oleh orang tuanya, dibiasakan memenej waktu, b. Teman sebaya yang memperoleh pembiasaan yang sama dalam keluarganya msing-masing.

c. Lingkungan sekolah kondusif sehingga anak taat pada peraturan sekolah..

2. Faktor internal anak taat peraturan di sekolah adalah:

Terinternalisasi nilai nilai dari pembiasaan pembiasaan yaitu:

a. Iman pada kitabulloh(AlQur'an)

b. Baca Al Qur'an

c. Melaksanakan peraturan $\mathrm{Al}$ Qur'an dan Al Hadits (baca syarat dan rukun sholat, puasa dan lain lain)

\section{Daftar Pustaka}

Abdur Rahman, Jamaal,2005, Tahapan Mendidik Anak Teladan Rasulullah, cetakan 1, Bandung: Irsyad baitus Salam.

Agustian, Ary Ginanjar, 2006, Emosional Spiritual Quatient, cetakan 27, Jakarta: Arga.

Ahmad, Al Hasyim,1993, Syarah Mukhtarul Ahaadits, cetakan 1, Bandung: Sinar Baru.

Ali Had, Al Haq, 1986, Mengasuh Anak menurut Ajaran Islam, Jakarta: UNICEF Indonesia

Bahrul, Khair Amal, Pendidikan Anak Usia Dini, 
http://www.waspada.co.id/ser ba serbi/pendidikan artikel. Php artikel id 67766

Crow, Lester D, Allice Crow, Z. Ksijan, Psikologi Pendidikan, Buku 1, Cetakan 1, Surabaya: Bina Ilmu

Jalaludin, 1977, Psikologi Agama, Cetakan 1l, Jakarta: Raja Grafindo persada

Jacinta, F. Rini, 2002, Konsep Diri, http://www.e-

psikologi.com/jenewa/160502 htm

John, Gotman, Joan De Claire, 2003, Kiat-Kiat Membesarkan Anak Yang Memiliki Kecerdasan Emosional, Alih Bahasa Hermaya, Cetakan 6, Jakarta PT Gramedia.

Jusuf, Amir Faisal, 1995, Reoreintasi Pendidikan Islam, Cetakan 1, Surabaya: Bina Ilmu

Malawi, Ibadullah, 2007, Statistik Lanjut, Madiun: F.I.P.IKIP PGRI.

Malik B Badri, 1986, Dilema Psikologi Muslim, terjemahan SitiZainla Hurfiati, Jakarta: Pustaka Firdaus.

Mar'at, Sikap Manusia, Perubahan Dan Pengukurannya, Jakarta: Ghali Indonesia.

Marfuah Panji Astuti, 4Tipe Pola Asuh Orang Tua, hhtp://www.tabloit.nakita.co $\mathrm{m} /$ hasanah 06279-02htm

Muh.Nazir, Metode Penelitian, Cetakan 1, Jakarta: Galia Indonesia.

Moh. Shohib, 1998, Pola Asuh Orang Tua Dalam membantu Anak Mengembangkan Disiplin Diri, Cetakan 1, Jakarta: Reinika Cipta.
Petranto, Ira, Rasa Percaya Diri Anakadalah Pantulan Pola Asuh Orang Tuanya, http://dwpp.jenewa., Swisse.com/buletin/?,Cetakan 5

Sudjono, Nana, Ibrahim, 2001, Penelitian dan Penilaian Pendidikan, Cetakan 11, Bandung: Sinar Baru Al Gesnida.

Saifuddin Azwar, Sikap Manusia Teori dan Pengukurannya, Cetakan 1, Yogyakarta: Liberty

Suhardi, Metodologi Penelitian dan Prakteknya, Cetakan 1, Jakarta: Bumi Aksara.

Suharsini Arikunto,1993, DasarDasar Evaluasi Pendidikan, Cetakan 1, Jakarta: Bumi Aksara.

Tafsir, Ahmad, 1999, Metodologi Pengajaran Agama Islam, cetakan IV, Bandung: Remaja Rosda Karya.

Ummu Dini, 2004, Tarbiyatul Aulad, hhtp://www pks. Anz.org/modulus,php?namil= news file $=$ artick sid $=$

Daryanto, 1998, Kamus Lengkap Bahasa Indonesia, cetakan 1, Surabaya: Apollo.

Departeman Agama Republik Indonesia, 1998, Al-Qur'an Dan Terjemahannya, Juz 1Juz 30, Surabaya: Mahkota.

Departemen Pendidikan dan kebudayaan, 1995, Kamus BesarBahasa Indonesia, Jakarta: Balai Pustaka.

Hasbullah, 1999, Dasar-Dasar Pendidikan, Cetakan 1, Jakarta:Raja Grafinda Persada 
Hurlock, Elizabet B, 1980, Psikologi Perkembangan Anak, Suatu Pendekatan Sepanjang rentang kehidupan,ES.D, Alih Bahasa, istidayanti, Sudjarwo, jakarta: Erlanga.

Siti Suhartini Haditomo, 2004, Psikologi Perkembangan
Pengantar Dalam Berbagai

Bagiannya, Yogyakarta:

Gadjah Mada University Press

Sugiyono, 2013, Metode Peneitian

Kombinasi(Mixed Methods),

Bandung:

Alfabeta. 